\title{
Utilitzant visualitzadors moleculars a Secundària
}

\author{
Carmen Fernández Hierro \\ IES Salvador Dalí (El Prat de Llobregat) \\ cfernand@xtec.cat
}

Actualment disposem de diversos programes per visualitzar i manipular estructures en tres dimensions. Hi ha una àmplia disponibilitat d'aquests models amb el format adequat per poder ser mostrats i manipulats en pàgines web o directament dins dels diferents programes.

El canvi químic sol resultar atractiu per als estudiants en una primera aproximació. Els canvis de color, l'emissió de llum, els despreniments de gasos... són seguits amb interès entre l'alumnat que es sorprèn i demana més exhibicions similars. I si són més espectaculars, millor.

Però malgrat aquest primer entusiasme, l'estudi de les reaccions químiques i del model de matèria que hi ha darrera esdevé difícil per a l'alumnat, i molts estudiants es queden en el camí d'intentar interpretar el que està passant.

\section{Visualitzadors moleculars}

Actualment disposem de diversos programes per visualitzar i manipular estructures en tres dimensions. Hi ha una àmplia disponibilitat d'aquests models amb el format adequat per poder ser mostrats i manipulats en pàgines web o directament dins dels diferents programes.

Les representacions poden girar i d'aquesta manera s'aprecia millor la distribució dels àtoms i els angles d'enllaç. A més, com es poden utilitzar diferents representacions (model compacte, de boles i bastons, de bastons, etc.), l'alumnat principiant pot entendre millor que els models són diferents aproximacions per poder representar la realitat.

Al llarg d'aquest l'article intentaré fer una passejada a través d'aquests recursos no massa utilitzats a secundària.

En primer lloc mostraré els programes més estesos per la xarxa. Després faré referència a algu- nes adreces web que contenen bases de dades de representacions de molècules en diferents formats, i finalment mostraré alguns exemples senzills que permeten dissenyar activitats fent servir aquest tipus de recursos.

\section{Els visualitzadors moleculars més estesos en la xarxa}

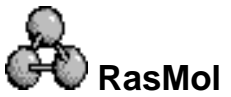

És un programa creat per a la visualització de representacions estructurals tant de molècules petites com d'estructures gegants. Els fitxers d'entrada de les molècules poden tenir diferents formats: Brookhaven Protein Databank (PDB), Tripos Associates' Alchemy y Sybyl Mol2, Molecular Design Limited's (MDL) Mol, Minnesota Supercomputer Center's (MSC) XYZ (XMol) i CHARMm.

La molècula, una vegada carregada, es pot mostrar de diferents formes (fig. 1). Es pot girar, ampliar i desplaçar. La imatge també es pot exportar a una varietat de formats gràfics com per exemple GIF i BMP.

Per conèixer més detalls sobre el programa es pot visitar la pàgina de RasMol o consultar les informacions i traduccions dels manuals que s'han fet en castellà. 


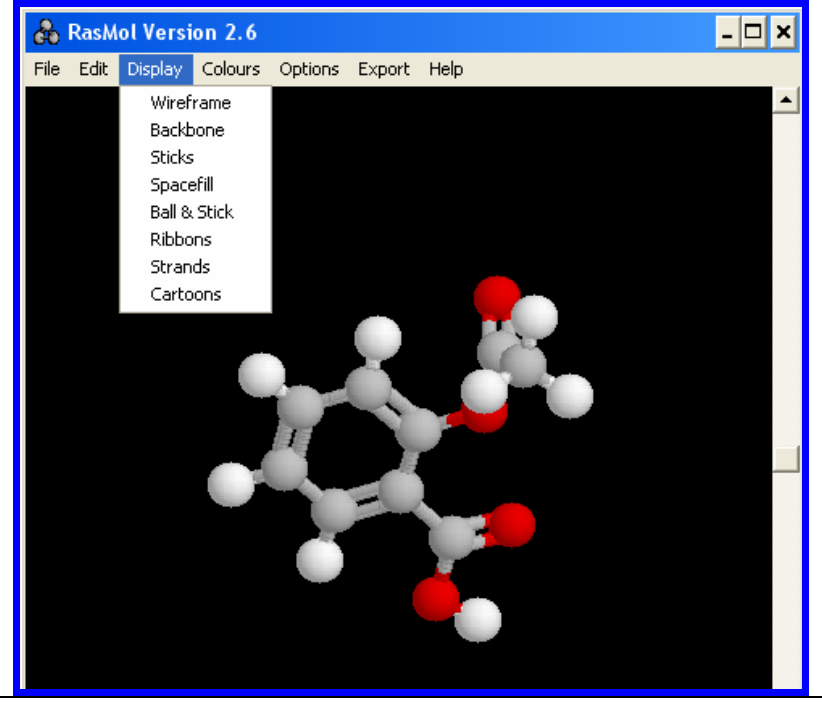

Figura 1. La finestra mostra la molècula d'aspirina (Ball \& Stick) i el menú RasMol.

\section{Now!
Now! Chime}

És un programa (plug-in) desenvolupat a partir de RasMol que fa possible aplicar les propietats de RasMol a través d'un navegador com ara Explorer o Firefox. En aquest cas es pot accedir al maneig interactiu de les molècules fent servir el menú emergent (fig. 2) que surt en clicar damunt de la molècula amb el botó dret del ratolí.

Per descarregar el programa és necessari registrar-se gratuïtament.

Cal dir que per veure i manipular les molècules de les pàgines que fan servir Chime és necessari tenir el programa instal.lat a l'ordinador.

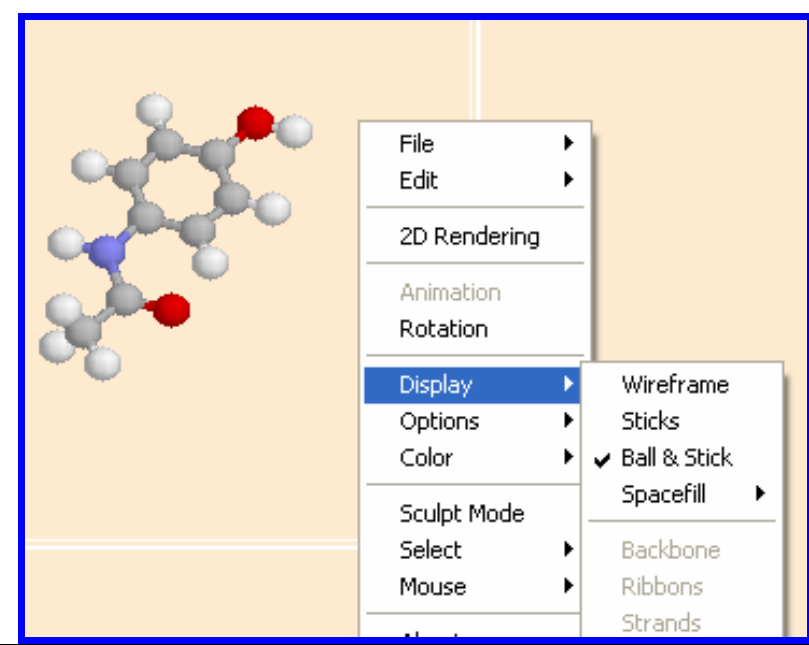

Figura 2. Molècula de paracetamol i menú emergent de Chime.

Per conèixer més coses sobre Chime, enregistrar-se i descarregar l'aplicació es pot visitar $\underline{M D L \mathbb{R}}$
Chime. I per accedir a una guia de Chime en castellà es pot consultar la pàgina BioROM 2006.

\section{STriol $\mathrm{Jmol}$}

És un visualitzador molecular gratuït amb característiques similars als anteriors però amb l'avantatge de no necessitar plug-ins addicionals per als navegadors (fig. 3).

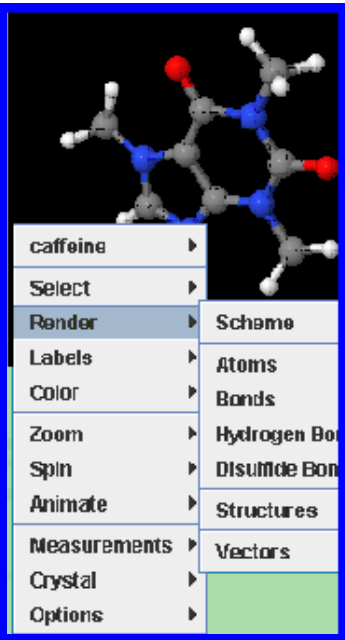

Figura 3. Menú de Jmol i molècula de cafeïna.

Per poder visualitzar i manipular les molècules s'ha de disposar de Java 1.4 o superior. Però això no sol ser problema ja que el software de Java es troba descarregat en molts ordinadors perquè es necessita per poder mostrar els applets escrits en aquest llenguatge.

Per conèixer més detalls d'aquest visor molecular es pot consultar l'espai web de sourceforge, que disposa de molta informació en castellà, anglès i francès.

\section{On trobar gràfics de representacions moleculars?}

Els arxius de molècules necessaris per visualitzar-les mitjançant els programes esmentats es poden trobar i descarregar en diferents llocs de la xarxa. En alguns casos hi ha disponibles arxius .zip i en altres es fa necessari desplegar el menú emergent de la molècula.

Els arxius de molècules més estesos al llarg de la xarxa tenen una extensió .mol i .pdb. Els fitxers es poden deixar en el disc dur de l'ordinador personal amb l'opció File del menú. Per tenir una idea més detallada de les seves propietats, i en concret dels fitxers .pdb, es pot consultar la pàgina: 
Academia Colombiana de Ciencias Físicas y Naturales.

Algunes adreces interessants en les quals es poden trobar arxius de molècules i cristalls són:

\section{- Alphabetical Listing of Molecules}

http://www.wellesley.edu/Chemistry/Flick/molecules Inewlist.html

\section{- Molecular Models}

http://www.molecularmodels.ca/molecule/molecule index.html

\section{- Structures of Inorganic Crystals}

http://www.chem.Isu.edu/lucid/maverick/crystals.ht $\underline{\mathrm{m}}$

\section{- Crystal Structures of Binary Inorganic Compounds}

http://www.molecules.org/binarycpds.html\#NaCl

Unes altres pàgines interessants que fan servir $\mathrm{Jmol}$, i a partir de les quals també es poden descarregar arxius de molècules són:

\section{- The Virtual Museum of Minerals and Molecules}

http://www.soils.wisc.edu/virtual museum/displays. $\underline{\mathrm{html}}$

\section{- ChemExper Chemical Directory}

Base de dades amb unes 7000 molècules.

http://www.chemexper.com/

\section{Exemples d'activitats amb els vi- sors moleculars}

La pàgina Structure and Bonding mostra algunes activitats en las quals es fa servir Chime per aprofundir en els conceptes d'estructura molecular i enllaç.

Alguns exemples senzills d'utilització dels visors podrien ser:
- Variar mitjançant els menús la representació de les molècules (fig. 4). Aquesta aplicació pot ajudar a entendre millor que les representacions moleculars només són models que ens ajuden a interpretar la naturalesa de les substàncies.
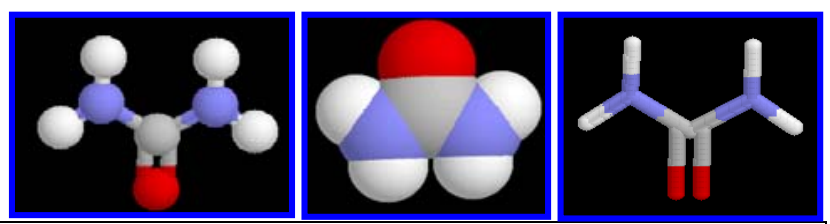

Figura 4. Diverses representacions de la molècula d'urea.

- Mostrar que la distribució espacial dels àtoms permet explicar les propietats de les substàncies. Per exemple, es pot aprofitar que les estructures es poden girar, ampliar i rotar per descriure millor les diferents representacions espacials del grafit i del diamant (fig. 5).

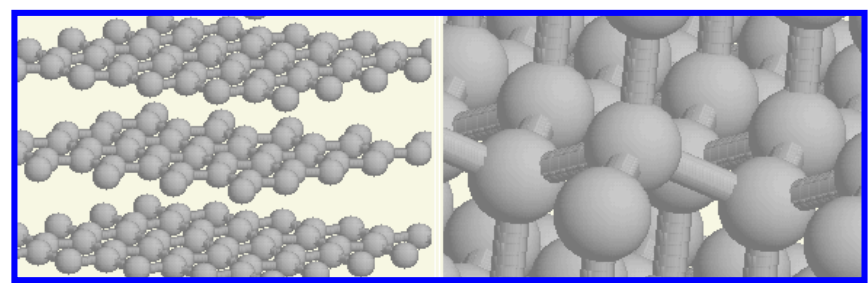

Figura 5. Estructura del grafit (esquerra) i del diamant (dreta).

- Fer servir el menú per mesurar distàncies i angles d'enllaç i així mostrar la geometria diferent de molècules com $\mathrm{BF}_{3} \mathrm{i} \mathrm{NF}_{3}$ (fig. 6).

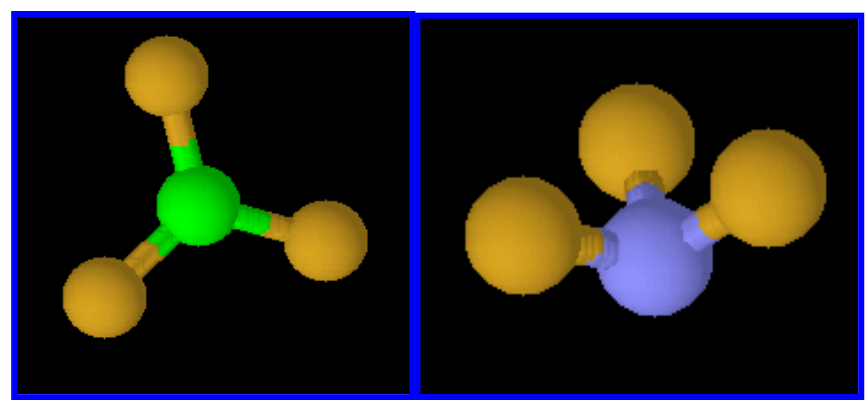

Figura 6. Estructura del $\mathrm{BF}_{3}$ (esquerra) i del $\mathrm{NF}_{3}$ (dreta).

- Mesurar les distàncies d'enllaç en les molècules d'età, etè i acetilè (fig. 7) i comparar-les. 


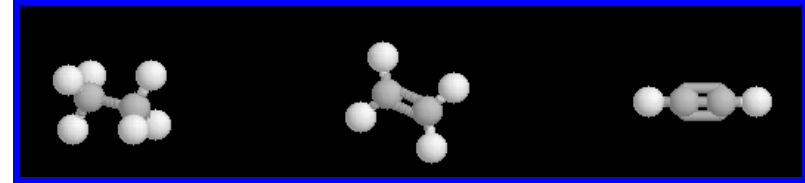

Figura 7. Molècules d'età, etè i acetilè (d'esquerra a dreta).

Els exemples proposats són només algunes aplicacions senzilles, però els programes permeten situacions més complexes. (Vegeu la pàgina que mostra la molècula d'insulina en la qual s'han posat botons per il.lustrar diferents aspectes de la molècula, així com la guia d'utilització de chime en la qual es mostren diferents usos del menú).

Alguns exemples de pàgines web que fan servir Chime o Jmol per l'ensenyament de la Química i la Biologia a secundària són:

- Estructuras y enlaces químicos. Pàgina de José Luís Cebollada, professor de l'IES Joaquín Costa de Cariñena.

- Què hi ha per dins? Activitat que vaig dissenyar com a recurs per ajudar a resoldre una "cacera de tresor" sobre classificació de la matèria.

- Biomolècules en 3D. Pàgina de Silvia Lope, professora de l'IES la Llauna de Badalona.

Cal recordar que per visualitzar i manipular tridimensionalment les representacions que es mostren en les pàgines web que fan servir visors mole- culars, s'han de tenir instal-lats en l'ordinador els

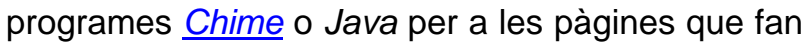
servir $\mathrm{Jmol}$.

Però també es pot treballar directament amb els visors moleculars sense necessitat d'estar connectat a la xarxa, sempre que es disposi en el disc dur de l'ordinador del visualitzador molecular adequat i dels arxius de molècules que es volen manipular.

Finalment caldria precisar que justificar els canvis químics requereix cert nivell d'abstracció. L'ensenyament de la Química i la Biologia necessita utilitzar dibuixos i construccions tridimensionals per tal d'ajudar l'alumnat a imaginar i interpretar les estructures i propietats de les diferents substàncies, de l'enllaç entre els àtoms o el canvi químic. Aleshores, els programes que permeten crear i manipular representacions de molècules en dues o tres dimensions són nous recursos que poden enriquir i afavorir l'aprenentatge d'aquests coneixements, alhora que permeten fer servir les noves tecnologies i l'àmplia disponibilitat de materials que hi ha a la xarxa.

Les dificultats d'aprenentatge no es resolen únicament amb aquests recursos, però és evident que aquestes representacions ens poden ajudar ja que superen de llarg els dibuixos que molts de nosaltres som capaços de fer. Tot i que no està de més fer construir manualment als alumnes algun model molecular senzill, els visors ens permeten treballar amb una varietat molt més àmplia de molècules $\mathrm{i}$ estructures tridimensionals. 